СЕЛЕЗНЕВ Павел Сергеевич - доктор политических наук, доцент департамента политологии и массовых коммуникаций Финансового университета при Правительстве РФ (125993, Россия, 2. Москва, Ленинградский $п р-\kappa m, ~ 49)$

СОЛОВЬЕВ Павел Вячеславович - студент Финансового университета при Правительстве РФ (125993, Россия, г. Москва, Ленинградский пр-кт, 49)

\title{
К ВОПРОСУ О ВИДАХ ДЕМОКРАТИИ
}

Аннотация. В статье рассматривается классификация демократии, обосновываются положительные и отрицательные ее стороны. Авторы предлагают дополнить ее теоретическую классификацию такими видами, как подлинная и мнимая демократия.

Ключевые слова: прямая, представительная, плюралистическая, плебисцитарная, подлинная, мнимая демократия

$\Pi$ онятие «демократия» означает власть народа. Общественно-политическое явление «демократия» - более широкое, чем просто власть народа. С понятием демократии связывается не только «власть народа» как таковая, но и общественный, политический строй. Под демократией зачастую понимается форма организации правящей государственной, народной и легитимной власти ${ }^{1}$.

О демократии в Античности в своих философских трудах писали Платон и Аристотель, Ксенофонт и Полибий, Цицерон и другие философы, где демократия используется для обозначения общественного строя.

Этот строй имеет своеобразный режим и предусматривает следующие условия:

- уважительное, терпеливое отношение к мнению меньшинства;

- равноправие граждан независимо от национальности, вероисповедания;

- признание в обществе широких естественных, политических и социальных прав, закрепленных в законе, гарантирующем их реализацию;

- выборность и подотчетность органов государственной власти и управления, должностных лиц своим избирателям;

- гласность в деятельности государства [Румянцев 2014].

В целом, если повнимательней рассмотреть их, становится очевидным, что это принципы, на которых строится демократическое управление. Оно также нашло свое отражение на современном этапе - в Конституции РФ2.

В целом демократия - это форма организации государственной власти и порядок властеотношений, при которых последовательно осуществляются основные права и свободы человека и гражданина, реализуется правовой порядок взаимоотношений личности и государства на началах взаимной ответственности, реально утверждается режим правовых ограничений и законности в деятельности носителей публичной власти, обеспечивается приведение общества к согласию и равновесию [Коркунов 2009: 347].

Государственная власть - это высшая власть в обществе, ее решения обязательны. Она осуществляется всеми государственными органами и должностными лицами государства, сплоченными в единое управленческое ядро. Государственную и политическую власть понимают в широком и узком значении: государственная власть считается более узкой категорией, а политическая

\footnotetext{
${ }^{1}$ Иванец Г.И., Калинский И.В., Червонюк В.И. Конституционное право России: энциклопедический словарь. М.: Юридическая литература. 2012. 432 с.

2 Конституция РФ (принята народным голосованием 12.12.1993) (с учетом поправок от 30.12 .2008 № 6-ФК3, 30.12.2008 № 7-ФК3, 05.02.2014 № 2-ФК3, от 21.07.2014 № 11-ФК3). - Собрание законодательства РФ. 04.08.2014. № 31. Ст. 4398.
} 
- более широкой. В понятие государства включены три основных признака: население (народ), территория, господствующая публичная власть.

Государственный режим входит в понятие «политический режим», охватывает не только понятие «государство», но и иные системы общества и их организации. Основными типами режимов являются авторитарный, демократический, тоталитарный, расистский (антидемократический). Государственной власти присущи свойства всеобщности (без которой общественная жизнь немыслима), инклюзивности (способности проникать во все сферы деятельности, связывать людей и общественные группы), регулятивности (регулирует общественные отношения), силы (воздействия, подчинения), реализация которых осуществляется путем применения методов убеждения и принуждения, которые зависят от властвующего в государстве лица и подвластных.

Например, авторитарный режим сосредоточивает огромные властные полномочия в руках главы государства, роль парламента и состава правительства в целом имеет формальный характер, ограничивается роль выборных и иных государственных органов, но усиливается позиция исполнительной власти, ограничиваются либо исключаются права и свободы граждан, запрещается деятельность оппозиционных партий и других общественных и политических организаций.

Демократический режим имеет следующие признаки:

- разделение властей;

- выборность и сменяемость центральных и местных органов власти;

- существование политических партий, в т.ч. оппозиционных;

- официальное признание принципов конституционности и законности;

- конституционное провозглашение и осуществление прав, свобод и обязанностей граждан с учетом их социально-экономических и политических интересов;

- создание эффективных механизмов прямого воздействия населения страны на характер государственной власти (через избирательную систему), осуществление контроля избирателей за деятельностью государственных органов.

Таким образом, форма государства включает в себя: 1) форму правления; 2) форму государственного устройства; 3) государственный режим.

Под формой государства понимается устройство высшей государственной власти, ее организация, которая имеет определенное содержание: это порядок образования и организации высших органов государственной власти, управляющей страной; способ территориального устройства государства, определенный порядок взаимоотношений центральной, региональной и местной властей; приемы и методы осуществления государственной (политической) власти.

Сказанное позволяет констатировать, что форма государства синтезируется из 3 основных элементов, которые, в свою очередь, находятся в прямой зависимости друг от друга: это формы государственного правления, государственного устройства, государственного режима.

Различают 2 основных формы государственного правления, которые зависят от того, осуществляется управление государством единолично или коллективным избирающимся органом. Так, единоличное правление присуще монархии, во втором случае речь идет о республиканской форме правления или республике. Названные формы общепризнаны, они имеют и внутреннее качественное содержание, и различные виды.

Отличие двух основных форм государственного правления - монархии и республики - заключается в том, что они определяют, как осуществляется управление государством: одним лицом или «коллективным избирающимся органом». 
Общая классификация форм деления на республику и монархию является исторически первой признанной, однако с точки зрения юридического метода каждая из этих форм в чистом виде не встречается, а имеет иной вид с учетом формально-юридического и фактического характера.

Изложенное позволяет понять существуюшую взаимосвязь формы государства с формами правления (то есть, строение государственной власти: монархической и республиканской).

Одним из основных названных признаков монархической формы правления является престолонаследие, которое означает переход власти от одного представителя царствующего дома (династии) к другому после смерти по иерархии в родственном порядке.

В заключение следует сказать, что полномочия президента, так же, как и власти монарха, различаются в зависимости от того, является ли данное государство парламентарным или только представительным, т.е. ответственны ли министры перед парламентом или только перед главой государства.

Однако принципиального различия в пределах компетенции монарха и президента республики нет, и было бы неправильным говорить, что власть президента объемнее или шире власти монарха. Первое существенное отличие между ними кроется в основном признаке, который заключается в избираемости первого и передаче монаршего титула по наследству второго; во-вторых, - в привлечении к ответственности, т.к. президент республики может быть осужден за совершенное преступление, а монарх - нет.

С учетом характеристик современных республик с конституционной формой важно отметить, что различие между конституционными монархиями и республиками незначительно, как и различие между монархиями конституционными и неограниченными.

Основания хронологической периодизации, в частности внутри типа государства и права, как уже отмечалось, еще недостаточно выявлены в историкоюридической науке. Предложение избрать критерием хронологической периодизации изменение формы государства (как критерий) не дает возможности четко выделить качественно определенные периоды развития государства и права. К тому же в науке недостаточно разработаны категории содержания и формы применительно к государству. Названный единственный критерий периодизации не позволяет учесть все многообразие развития государства и права народов России. Например, выделение самостоятельного периода в истории российского феодального государства и права - периода феодальной раздробленности - не может быть объяснено лишь развитием формы феодальной монархии, т.к. наряду с феодальной монархией возникла и другая форма феодального государства - боярские аристократические республики в Новгороде и Пскове.

В науке политологии демократия имеет довольно обширную классификацию [Суворов 1984: 112-116]. Наука выделяет несколько форм демократии:

- прямую демократию, появившуюся еще в древности и предполагающую принятие государственных решений всеми гражданами страны;

- плебисцитарную демократию - народовластие с выбором авторитетного лидера, который принимает решения на основе одобрения всех граждан. Предшественник такой формы демократии - военная демократия, включающая элементы родового строя;

- плюралистическую (представительную) демократию - государственное устройство, в котором гражданское население выбирает представителя с целью делегирования ему права решать государственные дела [Концепции и определения... 2006]. 
Понятие «прямая демократия» («чистая демократия») связывается с элементами прямого (непосредственного) народовластия; такой режим существовал ранее и существует в обществе сегодня, поэтому она отнесена к научной категории, представляющей собой определенную правовую модель прямого и непосредственного народного правления, закрепленную системой законодательства (совокупность конституционно-правовых норм). Она, в свою очередь, включает в себя архаическую и модернистскую формы [Горбунова 2011: 56].

Для характеристики прямой демократии выделим ее особенности:

- принадлежность народу неотчуждаемых и непередаваемых властных полномочий, где народ - главный субъект власти;

- народное собрание - легитимный орган власти, избираемый народом, который принимает публично-властные решения по общественно и социально значимым вопросам;

- решения принимаются большинством;

- разделение народной власти на законодательную, исполнительную и судебную.

Понятие плебисцитарной демократии появилось в античное время, когда все решения принимались на народных собраниях путем голосования всех граждан. В Европе XX в. плебисциты неоднократно использовались для решения вопросов территориального размежевания (например, отделение Норвегии от Швеции).

Примером плебисцитарной демократии на текущий момент считается Швейцария, в частности, по форме народного управления. В этой стране довольно часто проводятся референдумы, которые имеют следующие виды:

- обязательные, если вновь принятый закон затрагивает конституцию страны;

- условные, которые могут проводиться по любому закону в течение 3 месяцев со дня его принятия, если в поддержку референдума удается собрать определенное число подписей;

- совещательные, которые проводит правительство или парламент, когда нет острой необходимости собирать общий совет [Астафичев 2014; Зорькин 2014].

Понятие «прямая демократия» («чистая демократия») - не вымысел, не фантазия. Оно - результат мыслительной деятельности, абстрагирования, анализа исторической сущности и анализа важнейших общих и существенных характеристик, в т.ч. признаков систем прямого (не представительного) правления прошлого. В какой-то мере это и результат попыток исследователей оценить реальные процессы, происходящие в современном обществе, угадать перспективы его развития, заглянуть в будущее.

Сложность исследования прямой демократии как непосредственного народного правления заключается в том, что приходится иметь дело лишь с основными началами и принципами прямого народовластия, которые наличествовали в бывших обществах и существуют в обществе современном. А потому прямая (чистая) демократия - это научная категория, обозначающая определенную правовую модель прямого народного правления, определяемую системой законодательства (совокупностью конституционно-правовых норм) и имеет две формы модели - архаическую и модернистскую.

Демократия, являясь общественно-политическим феноменом, однако, не исчерпывается приведенной основной классификацией и на сегодняшний день продолжает совершенствоваться, приобретая иную полярность и окраску.

Свой вариант теории плебисцитарной демократии предложил Макс Вебер, который считал, что такая демократия реальна, но при определенных условиях, таких как 1) общественная стабильность; 2) демократические традиции; 3) сильная оппозиция. 
В первом случае в условиях социальной напряженности, при наличии политических и экономических кризисов немногие могут сохранить здравый смысл и делать свой выбор осознанно. К примеру, уравновешенные, добропорядочные и педантичные немцы отдали в период кризиса предпочтение Гитлеру и его партии, а страна древней культуры - Грузия - вполне законно избрала своим президентом 3. Гамсахурдиа, от которого избавилась в период внутренней гражданской войны.

Второе условие - это развитие демократической традиции, включающее в себя воспитание и культуру демократических традиций. К примеру, этот вид действует сегодня в США, но он недопустим в Латинской Америке и иных странах.

При сильной политической оппозиции, имеющей доступ к средствам массовой информации, возможно формирование свободного общественного мнения, а не такого, которое выгодно власти.

Представительная демократия на сегодняшний день является ведущей формой участия граждан в управлении современными государствами, при которой основным источником власти признается народ, принимающий непосредственное участие в государственном управлении посредством избрания своих представителей в органы государственной власти и местного самоуправления (например, путем проведения референдума).

Современная представительная демократия трансформируется в модель, которая характеризуется значительной вовлеченностью граждан, общественных организаций, групп интересов и многих других субъектов гражданского общества в процесс выработки и принятия публично-властных решений.

Цензовая демократия - это некое подобие представительной демократии: здесь население выбирает не одного представителя, а целую группу, круг лиц, которому доверяет решение важных вопросов. Цензовая демократия может быть элитарной и классовой (пролетарская, буржуазная) [Гранкин 2012].

Формы демократии складываются (материализуются) как ее компоненты, оформляются в институты демократии, образующие в совокупности систему. Институт демократии - это структурно-нормативное и функциональное образование в организации государственной власти, обеспечивающее во взаимодействии с другими определенный порядок взаимовлияния общества и государства на пути к прогрессу.

На современном этапе идет интеграция различных форм демократии. Ключевой элемент здесь - народное волеизъявление, которое подразумевает обязательное наличие ветвей власти, образование которых происходит на основе тайных, всеобщих выборов. Также важным является развитие необходимых демократических элементов: свободы слова, печати, создания общественных организаций и пр.

Представительная демократия, в отличие от прямой демократии, учитывает эту сложную социальную дифференциацию. Она предоставляет возможность принимать взвешенные решения немногим выдвиженцам основных социальных слоев и групп граждан, принимая во внимание их реальный вес и влияние в обществе.

Прямая демократия ведет к так называемой тирании большинства [Румянцев 2014]. Прямому народному правлению имманентно стремление к подавлению инакомыслящего меньшинства граждан.

Недостатком прямой демократии может являться нежелание граждан заниматься постоянной управленческой деятельностью и иными мероприятиями, при этом проявится низкая эффективность решений из-за непрофессионализма большинства «руководителей», избранных народом. 
В таких случаях, как правило, народ предоставляет власть избранным от народа депутатам и другим органам исполнительной и судебной власти, которые и будут выражать мнение социальных групп, слоев, политических партий и общественных организаций.

Сегодня очевидно, что государство должно быть демократическим, поскольку только так решается проблема человека и государства. Следует выработать механизм деятельности государственной власти так, чтобы власть не узурпировалась и не шла вразрез с интересами народа и отдельных ее граждан.

Современная наука политология, совершенствуя данное направление, существенно расширила границы приведенной классификации форм демократии.

Например, Б.А. Исаев, исследуя политическую историю демократии, называет ее виды во взаимосвязи с эпохами: первобытную демократию, античную демократию древнегреческих полисов, античную демократию древнеримской республики, средневековую демократию, демократию Нового времени, демократию эпохи индустриализма, демократию постиндустриализма. Совершенно очевидно, что демократия прошла длительный путь своего развития и видоизменялась, при этом, как отмечают ученые, «ее распространение не всегда было закономерным и предсказуемым, а также линейным или однонаправленным» [Исаев 2012].

К примеру, Ю.Е. Поляк выделяет современный вид демократии - «электронную демократию», которая им связывается с западными средствами интернетпропаганды о деятельности правительства $e$-government, а в нашей стране - с так называемыми телекоммуникационными услугами сети Интернет - «электронной демократией», «электронным правительством» или «электронным государством» [Поляк 2011].

Надо сказать, что ученый отчасти прав, связывая этот вид демократии со свободным доступом граждан к официальной информации. Мы также согласимся с доводом, что «большинство граждан стремятся покинуть Россию, а молодые преимущественно заняты в сети Интернет и не ходят на выборы, не смотрят телевизор». С такими доводами действительно трудно не согласиться.

Таким образом, поскольку демократия в среде ученых довольно широко интерпретируется и классифицируется, то представляется, что современные взгляды на действующее «народовластие» может быть нами представлено в формах «подлинной» и «мнимой» демократии. Обоснуем сказанное.

Форма государственного устройства рассматривается в теории государства и права в различных аспектах: 1) как форма правления; 2) как способ территориального устройства государства с определенным порядком взаимоотношений центральной, региональной и местной властей; 3) как приемы и методы осуществления государственной (политической) власти.

Она проявляется во внутренней структуре государства, определяя правовое положение подведомственных частей (органов) и их взаимоотношения, устанавливая иерархию центральных и местных госорганов; в государственной форме - с учетом интересов нации того или иного государства.

Но есть и иные теоретические взгляды и позиции ученых. Так, еще в советский период к «содержанию» формы государства подмешивали классовую теорию. Полагаю, что в названной социалистической теории смешиваются два понятия: форма государства и форма правления.

Считается, что политический режим входит в понятие государственного режима. Он охватывает понятие не только государства, но и иных систем общества и их организации и представляет собой совокупность методов и способов управления власти, таких как демократический и антидемократический (недемократический). 
Основными типами режимов являются тоталитарный, авторитарный, фашистский, демократический режимы. Однако в современной теории приведена еще более современная классификация видов; фактически их делят на две большие группы: демократический и антидемократический (недемократический) режимы.

Выделим только основные моменты авторитарного и демократического режимов, раскроем содержание этих видов.

Авторитарный режим сосредоточивает огромные властные полномочия в руках главы государства, роль парламента и правительства в целом имеет формальный характер, ограничивается роль выборных и иных госорганов, но усиливается влияние исполнительной власти, ущемляются права и свободы граждан либо они вообще исключаются, запрещается деятельность оппозиционных партий, других общественных и политических организаций (одним из ярких примеров авторитарного режима является фашизм).

Демократический режим характеризуется принципом разделения властей; выборностью и сменяемостью центральных и местных органов власти; подразумевает существование политических партий, в т.ч. оппозиционных. При демократическом режиме официально признаются принципы конституционности и законности, провозглашаются и осуществляются права, свободы и обязанности граждан с учетом их социально-экономических и политических интересов; существуют эффективные механизмы прямого воздействия населения страны на характер государственной власти путем выборов, осуществляется контроль народа за деятельностью госорганов.

Такие виды государственных политических режимов, как авторитарный, тоталитарный и иные близкие к ним подвиды (фашизм), неизбежно приводят к краху власти и государственному перевороту. Но на сегодняшний день перевороты могут быть и политической инсценировкой при условии милитаризации общественной жизни, развития военно-промышленного комплекса вплоть до военных действий, о чем свидетельствует яркий пример - Украина.

Подводя итог, следует отметить, что настоящая демократия не может связываться с так называемыми выходцами из народа. Напротив, на наш взгляд, в современном обществе идет сильнейший раскол, возникающий вследствие недоверия граждан к правящей власти, в т.ч. к избранникам народа - депутатам, который проявляется в виде недоверия при принятии законов, идущих вразрез с мнением людей, при невыполнении депутатами наказов своих соотечественников, их выдвинувших, при неисполнении программ и отсутствии решения тех сложнейших вопросов, которые стояли и стоят перед государством (например, вопросы совмещения потребностей общества и отдельно взятых граждан). Именно поэтому очевидно, что существует потребность обоснования новых видов демократии - подлинной и мнимой.

\section{Список литературы}

Астафичев П.А. 2014. Демократия как основа доктрины конституционализма и конституционного строя современного государства. - Конституционное и муниципальное право. № 7. С. 19-23.

Гранкин И.В. 2012. Законодательное обеспечение прямой демократии на муниципальном уровне. - Конституционное и муниципальное право. № 7. C. 44-47.

Горбунова М.А. 2011. Демократия в России: модели, традиции, тенденции развития: дис. ... к.полит.н. Пятигорск. 131 с.

Зорькин В.Д. 2014. Конституционное правосудие стран новой демократии: вызовы и перспективы. - Журнал конституционного правосудия. № 3. С. 1-10. 
Исаев Б.А. 2012. Условия и факторы, периоды и циклы развития демократии. - Политическая экспертиза: Политэкс. СПб: Изд-во СПбГУ. Ч. 1. Т. 8. № 3. C. 273-291.

Коркунов Н.М. 2009. Лекции по общей теории права. СПб: Юрайт. 422 с.

Концепиии и определения демократии: антология (под ред. А.В. Фененко). 2006. М.: КомКнига. 224 с.

Поляк Ю.Е. 2011. Электронная демократия, вид сверху.- Информационные ресурсы России. № 5 (123). С. 5-10.

Румянцев А.Г. 2014. Минимальная теория демократии: смысл и пределы возможного. - Сравнительное конституционное обозрение. № 3. С. 24-41.

Суворов В.Н. 1984. Конституционные формы непосредственной демократии: дис. ... К.ю.н. М.: Всесоюзный юридический заочный институт. 134 с.

SELEZNEV Pavel Sergeevich, Dr.Sci. (Pol.Sci.), Associate Professor of the Department of Political Science and Mass Communications, Financial University under the Government of the Russian Federation (49 Leningradsky Ave, Moscow, Russia, 125993)

SOLOV'EV Pavel Vyacheslavovich, student of the Financial University under the Government of the Russian Federation (49 Leningradsky Ave, Moscow, Russia, 125993)

\section{ON THE QUESTION OF TYPES OF DEMOCRACY}

Abstract. The article considers the classification of democracy, substantiates its positive and negative sides. The authors propose to supplement the theoretical classification with such types of democtacy as genuine and imaginary ones.

Keywords: direct, representative, pluralistic, plebiscite, genuine, imaginary democracy 